\title{
THE FILIOQUE PROBLEM - HISTORY AND CONTEMPORARY RELEVANCE
}

\author{
Bernd Oberdorfer \\ University of Augsburg
}

\section{Introduction}

Why should we be interested in the Filioque problem? Why should we spend time on dealing with one of the most subtle subtleties of the doctrine of Trinity as the question whether in the eternal life of God the Holy Spirit "proceeds" "from the Father", "from the Father alone", "from the Father through the Son" or "from the Father and the Son" apparently is? And why should we put effort into understanding a detail within the tradition of the Nicean-Constantipolitanean Creed, a Creed which is (at least in German Lutheran churches) almost never ever used? Might there a question be imagined that seems to be more irrelevant to our present problems and tasks in Church and theology?

Surprisingly enough, the South African Theological Society has chosen to discuss the Filioque problem at its annual meeting. I would think that it did not do so due to as it were archaeological interests but rather convinced of the topic being particularly relevant to the churches in South Africa in the present time. And I would assume that the meeting will primarily focus on the question of how to describe the relation between Christ and the Holy Spirit, or, more exactly, how to understand the Holy Spirit as being the Spirit of Christ. And am I wrong to presume that the meeting will probably aim to emphasizing anew the importance of the Filioque, to wakening it out of its long time rest within the collections of creeds and confessions, to vitalizing an apparently outdated element of the tradition of the Western churches and giving it a new, fresh meaning within the debates of our time and age?

Although I totally agree with pointing out the crucial relevance of Christ to our understanding of the Holy Spirit and its revealing, renewing, life-giving work in individuals, church and world, my approach to the Filioque problem has been quite different. ${ }^{1}$ The Filioque problem, taken as such, has its proper place (its Sitz im Leben) in the history of the alienation between the Eastern (Greek) and the Western (Latin) churches beginning in the early Middle Age and resulting in very different and even contradictory settings of culture, liturgy and theology. Unlike some Orthodox theologians argue, the Filioque was not the reason of this alienation, but certainly one of its crucial aspects. And since Photios, Patriarch of Constantinople in the middle of the 9th century, it has been and still is a controversial theme in the discussions and negotiations between the Western and the Eastern churches. These discussions have intensified in the climate of ecumenical openness in the 20th century. ${ }^{2}$ They focused on the question of whether a way could be found to a form of the Nicean-Constantinopolitanean Creed $(N C)$ which at least the three

1. Cf. Bernd Oberdorfer, Filioque. Geschichte und Theologie eines ökumenischen Problems, Göttingen: Vandenhoeck \& Ruprecht 2001. Cf. also my dialogue with Elisabeth Gräb-Schmidt in: Wilfried Härle / Reiner Preul (Hg.): Marburger Jahrbuch Theologie, Bd. XII: Ökumene, Marburg 2000, 117-186 (esp. my: Filioque. Werbeschrift für ein Problem, ibid., 117-137). For a short outline cf. my article Filioque in: RGG4, Bd. 2, Tübingen: J.C.B. Mohr (Paul Siebeck) 2000, col. 119-121 (part II [col. 120] written by Karl Christian Felmy).

2. Cf. Lukas Vischer (ed.), Geist Gottes - Geist Christi. Ökumenische Überlegungen zur Filioque-Kontroverse. Bericht und Vorträge zweier Tagungen auf Schloß Klingenthal (Frankreich), Frankfurt (M) 1981 (= Beiheft zur Ökumenischen Rundschau Nr. 39). 
large confessional families (orthodox, protestant, roman-catholic) have in common, and that means: whether the Western churches were able to return to the original Greek form of the Creed without the Filioque. That raised a complex set of problems because it turned out to be not only a question of the hermeneutics of Creeds, but likewise and even more a question of the hermeneutics of trinitarian theology. And thus, the Filioque debate proved to be deeply involved in the discussions on what basis our knowledge of God's triune being has under the conditions of modernity. To say it with the famous words of Karl Rahner which have become a kind of communis opinio in 20th Century Western theology, the epistemological basis of any trinitarian thinking is that "the 'economical' Trinity is the immanent Trinity and vice versa", ${ }^{3}$ this means that we know about that and how God is triune only through understanding how the trinitarian 'persons' reveal themselves and their mutual relations in their acting towards and within the world. Although I am fully aware that this hermeneutical axiom has led Karl Barth to emphatically defending the Filioque as being indispensable to his conception of God and God's self-revelation, ${ }^{4}$ my thesis is that due to these changed hermeneutical conditions we are compelled to scrutinize very seriously the old arguments brought forward in favour of the Filioque to be a necessary element of trinitarian theology.

In the following, I would at first like to outline very shortly the history of the Filioque problem. As a second step, I will focus the wide range of Orthodox criticism of the Filioque on four crucial arguments that I will discuss with reference to Western anticriticism. In the third and final part, I would like to point out aporetic aspects of the Western as well as the Eastern tradition as being a challenge to a new approach. As I would think, this new approach has to be based on the complex description of the relations between Christ and the Holy Spirit within the biblical traditions of which the Filioque proves, to my opinion, to being not a false, but a one-sided and insufficient expression. When I therefore state it to be possible that the Western churches return to the Greek form of the NC, that does imply, as I will show in the end, neither adopting the Greek conception of Trinity as a whole nor condemning the Filioque as being heretic or doubting the actually indispensable truth it expresses: that the Holy Spirit is the Spirit of Christ.

\section{The History of the Filioque}

The roots of the controversy lie in the development of different forms of trinitarian thinking in East and West that nevertheless were not regarded as being controversial for several centuries.

In the East, ${ }^{5}$ Athanasius and the Cappadocians developed the terminological distinctions and the conceptual framework enabling the church to overcome the Arian crisis that had been rather increased than resolved through the council of Nicea 325 with its homoousios-formula. The task provoked by the Arian criticism was to defend monotheism and at the same time maintain the claim of Christ being God in a full sense. Athanasius 6 based the differentiation in God on the three names revealed in Christ's commandment to baptize all people "in the name of the Father and the Son and the Holy Spirit" (Mt 28,19) and rejected any further attempts to deeper exploring the secrets of God as being

3. Cf. Karl Rahner, Bemerkungen zum dogmatischen Traktat "de trinitate”, in: id., Schriften zur Theologie, Vol. IV, Einsiedeln 1960, (103-133) 115 (my translation). Cf. Eberhard Jüngel, Das Verhältnis von “ökonomischer” und "immanenter” Theologie, in: ZThK 72 (1975), 353-364. See my Filioque, 371-388.

4. Cf. Karl Barth, KD I/1, Zürich 1932, 496-511. See my Filioque, 354-371.

5. For the following, cf. my Filioque, 64-96, or my shorter Werbeschrift, 123-125.

6. Cf. my Filioque, 69-75. 
illegitimately inquisitive. ${ }^{7}$ This connection of a strictly biblical basis and an 'apophatic' cautiousness became characteristic of the Orthodox tradition as a whole. It was also respected by the Cappadocians although they went quite further in conceptual explication than Athanasius had done. ${ }^{8}$ Basil of Caesarea ${ }^{9}$ established the distinction between mia ousia and treis hypostaseis. To Gregory of Nazianzus ${ }^{10}$ we owe the basic concepts for the difference between the three modes of being in God: agennesia (ungeneratedness), gennesis (generation) and ekporeusis (procession). The latter concept (once again a biblical term, taken from John 15,26) obviously is being chosen in analogy to the Son, who is identified by his origin from the Father. So their respective relation of origin to the Father becomes decisive to the personal identity of the Son and the Holy Spirit. Yet, unlike the Latin tradition later put it, "relation" 11 is not used as a general term for the classification of any real differentiations in God but rather restricted to the two concrete relations of "generation" and "procession" which as such constitute the persons of the Son and the Holy Spirit, and thus the orthodox tradition never felt the necessity of stating a relation of origin between Son and Spirit. Gregory of Nyssa, ${ }^{12}$ however, stated that distinction more precisely by saying that the Son is the "only one who is being generated" (monogenes) ${ }^{13}$ and the Holy Spirit proceeds "from the Father through the Son". In certain regard, that comes quite close to the Filioque. But Gregory does not speak of Christ as an origin of the Spirit. On the contrary, according to him, the only aition (origin, cause) in God is the Father whereas both the Son and the Spirit are aitiata (originated, caused), the Spirit, though, through the mediation (mesiteia) of the Son. ${ }^{14}$

Interestingly enough, the formula dia tou hyiou did not find its way into the NC of $381 .{ }^{15}$ Actually, the NC does not say a word about the relation between the Son and the Holy Spirit. It states: "We believe in the Holy Spirit, who is Lord, who makes alive, who proceeds from the Father, who is worshipped and glorified together with the Father and the Son ..." Presumably, the fathers felt that any further comments could be misunderstood in a subordinationist sense which would have been quite uncomfortable to their struggle against the "Pneumatomachians" who challenged the full divinity of the Holy Spirit. Anyway, there is a controversial debate up to the present time on whether the silence of the fathers of Constantinople means that they deliberately wanted to exclude any originative participation of the Son in the procession of the Spirit (and that is what most of the orthodox theologians think).

The father of Western trinitarian theology was Augustine. ${ }^{16}$ Without knowing the NC (which was declared and acknowledged as being the confession of the 381 council not before Chalcedon 451), and without polemical purpose against the Greeks, he unfolded,

7. Cf. Athanasius, Ad Serapion I 18 (PG 26, 573 AB).

8. Cf. my Filioque, 75-96. Still important is the brilliant study of Karl Holl, Amphilochius von Ikonium in seinem Verhältnis zu den großen Kappadoziern, Tübingen / Leipzig 1904 (reprint Darmstadt 1969).

9. Cf. my Filioque, 76-83.

10 Cf. my Filioque, 83-88.

11. Cf. Gregory of Nazianzus, or. 31,9 ; or. 29,16 .

12. Cf. my Filioque, 88-94. See also Werner Jaeger, Gregor von Nyssa's Lehre vom Heiligen Geist. Posthumously ed. by Hermann Dörries, Leiden 1966.

13. Cf. Holl, loc. cit., 212 sq. (with many references).

14. Cf. Gregory of Nyssa, Quod non sint tres dii, in: Opera III/1, Leiden 1958, 56 (= PG 45, 133 B). Cf. Holl, loc. cit., 214

15. Cf. my Filioque, 97-106.

16. Cf. my Filioque, 107-128. 
based on the Nicean Creed of 325, a "neo-Nicean" conception of Trinity ${ }^{17}$ which was in certain respects characteristically different to the conception of the Cappadocians. Particularly, three aspects are relevant to our question: Firstly, his trinitarian pneumatology is based on the formula that the Holy Spirit is the Spirit of the Father and the Son. ${ }^{18}$ Secondly, he formalized the concept of relation to being a category between substance and accidence that allowed him to state real (that means: non-accidental) distinctions in God without endangering the unity of the divine essence. And thirdly, he understood the Holy Spirit as being the mutual community of the Father and the Son, the tie of their mutual love and their unity. From that he concluded that the Spirit also "proceeds from the Father and the Son" (cf. de Trin XV/26,45), albeit "principaliter a Patre" (ibid., 26,47).

Evidently, Augustine's conception enclosed a Filioque. A Filioque problem, though, did not exist before this conception was linked to the process of the spreading and translation of the NC in the Latin speaking world. ${ }^{19}$ That happened first in Spain, in the Toledonian synods of the late 6th and the 7th century. Yet, although we know that these synods have emphasized Christ as (in communion with the Father) being the origin of the Spirit in order to prove his full divinity against an Arianism still living among the Goths, we have no certain witnesses whether the $\mathrm{NC}$ has been used then including the Filioque addition. ${ }^{20}$ We have also to take into consideration that there was not an authoritative Latin translation of the NC in that time. Things were in a state of flux. And anyway, Spain was remote from the centre; no one would notice. The common picture that the Western church changed the authentic text of the Creed which had its proper place in liturgy through a deliberate authoritarian act reflects at best the situation of the 11th century after Pope Benedict VIII 1014 introduced the recitation of the 'filioquist' NC into the Roman mass canon. Two centuries earlier, in the beginning of the 9th century, emperor Charles the Great whose theological advisers strictly defended the Filioque had failed in convincing Pope Leo III to do the same. Leo, although confirming the doctrine of Filioque to be true, nevertheless was not willing to touch the ecumenical creed. ${ }^{21}$

About fifty years later, the first Greek theologian who polemized against the Filioque was Photios. ${ }^{22}$ In his extensive Mystagogia ${ }^{23}$ he aimed at proving that the Filioque contradicted not only the clear voice of Christ witnessed in John 15,26, that he will send the Holy Spirit to the disciples which nevertheless "proceeds from the Father" (this is the fundamentum inconcussum of any orthodox criticism), but also contradicts the unanimous witness of the apostles, Church fathers, councils and even popes (gratefully, he referred to Leo III). Moreover, he demonstrated in full detail which theological confusions and heresies were caused by that misunderstanding. His basic argument was that the Filioque destroys the mono-principality of the Father, and therefore he stated that the NC clause of

17. Cf. Peter Gemeinhardt, Lateinischer Neunizänismus bei Augustinus, in: ZKG 110 (1999), 149-169.

18. Cf. De trinitate. I/4,7; 5,8; IV/20,29; V/11,12; XV/26,45 et al.

19. To the following, cf. my Filioque, 129-150.

20. The discussion is controversial. José Orlandis and Domingo Ramos-Lisson (Die Synoden auf der Iberischen Halbinsel bis zum Einbruch des Islam [711], Paderborn et al. 1981, 206) argue that at the 8th synod of Toledo (653) the NC was recited including the Filioque. According to Reinhard Slenczka, however, the documents of the pre-Carolingian time provide no evidence that the NC has been used then in a filioquistic form (Das Ökumenische Konzil von Konstantinopel und seine ökumenische Geltung heute, in: Una Sancta 36 [1981], 298-309).

21. Cf. my Filioque, 143-150.

22. Cf. my Filioque, 151-164.

23. PG 102, col. 279-400. English translation: Saint Photios, The Mystagogy of the Holy Spirit. Translated with an introduction by Joseph P. Farrell, Brookline, MA 1987. 
the Spirit "who proceeds from the Father" has to be interpreted in an exclusive sense: "only from the Father" (ek monou tou patros).

But it would be wrong to assume that, after Photios, the Filioque question immediately and constantly had a proper and prominent place in the controversies between the West and the East. In the events of 1054, for example, retrospectively regarded as the date of the Schism, it did not play a crucial role (grotesquely enough, Humbert of Silva Candida, the Roman legate, accused the Greeks to having omitted important words in NC, namely the Filioque!). It took several centuries of increasing alienation until the Filioque, that is, the ek monou tou patros became a kind of password betraying on which side you are.

In the West, ${ }^{24}$ the Augustinian conception of Trinity was developed to an even more formalized shape. Anselm of Canterbury ${ }^{25}$ unfolded a conception of the trinitarian distinctions according to which "all in God is undistinctly one unless an opposition of relations of origin occurs" (in Deo omnia sunt unum ubi non obviat aliqua relationis oppositio). ${ }^{26}$ Therefore, the Son and the Holy Spirit would be indistinguishable (or even more: they would not be distinct) if there were not a relation of origin between them, and because the Spirit cannot be origin of the Son, ${ }^{27}$ the Son must be origin of the Spirit, and quod erat demonstrandum. ${ }^{28}$ Thomas Aquinas even strengthened this argument defining the trinitarian persons as being a respective relatio subsistens. ${ }^{29}$ Anselm had also defended the right of a regional church to add interpretative amendments to the Creed if that is necessary to fight heresies. And to his opinion, this had been the case in Spain and in the Carolingian empire when Arianism had to be rejected. ${ }^{30}$ In high Middle Age, this argument was transformed and linked to the theory that gave the pope the authority to decide matters of doctrine and discipline on behalf of the church as a whole. That strictly contradicted the Greek conviction that decisions of universal concern were only legitimised when confirmed by the community of the five patriarchies represented within an ecumenical council.

The Latin doctrine of the procession of the Spirit from the Father and the Son, being nevertheless a single act realized in the indistinct unity of both of them (as Aquinas put it: one spiratio with two spirantes, but not two spiratores), ${ }^{31}$ was dogmatised in the 4 th Lateran council in 1215 (DH 800). The council of Lyon 1274, that was meant to be a council of reunion, set a slight counterbalance by stressing the principaliter a Patre aspect but, on the other hand, anathematised anyone who dared explicitly reject the Filioque (DH $850)$. No wonder, that it was not very successful. At the council of Ferrara and Florence (1 438/39), ${ }^{32}$ after long and intensive discussions, the Greeks (with few exceptions of which the most famous is Mark Eugenicus) accepted the declaration "Laetentur caeli" (DH 13001308, especially 1300-1302) which pointed out the Latin doctrine of Filioque as being an

24. Cf. my Filioque, 168-202.

25. Cf. his De processione Spiritus Sancti, in: Opera Omnia, ed. F. Schmitt O.S.B., Tomus I, Vol. II, StuttgartBad Cannstatt 1968, 175-219.

26. Loc. cit., 181.

27. There are only two forms of relations of origin in God, generation and procession. If the Spirit generated the Son, the Son would be the Son of the Spirit. If the Son proceeded from the Spirit, he would be the Spirit of the Spirit. Both is absurd. This argument, as obvious, implies that a generated entity is a Son wheras a proceeding entity is a Spirit.

28. For Anselm's argument, see my Werbeschrift, 128 sq.

29. Cf. Summa Theologia I q.29,4.

30. Cf. my Filioque, 176-178.

31. Summa Theologia I q.36,4.

32. To the following, cf. Hans Jürgen Marx, Filioque und Verbot eines anderen Glaubens auf dem Florentinum. Zum Pluralismus in dogmatischen Formeln, St. Augustin 1977. See also my Filioque, 236-258. 
equivalent (and, as it were, a better expression) of the Greek dia tou hyiou. The Greeks approved because they had been convinced that, on the one hand, the Filioque was rooted much stronger in the tradition of the Latin fathers than they had been aware of before, and that, on the other hand, their own patristic tradition did not entail that strict rejection of any participation of the Son in the procession of the Holy Spirit as Photios had made them believe. But the Latins went too far: They urged the Greeks to accept the Son being called the "causa" of the Spirit although the Greek Fathers never had used the word aitia with reference to the Son. In my opinion, this is the most relevant theological reason for the eventual failure of the reunion.

As far as the doctrine of Trinity is concerned, the Reformers deliberately emphasized their accordance with the Roman church - which appreciated that explicitly (cf. CA 1 to the affirmative comment of the Confutatio) ${ }^{33}$ As an element of that, without comprehending that there was a problem, they also adopted the doctrine of the procession of the Spirit from the Father and the Son that seemed to fit quite perfectly to their Christocentric approach. Likewise, the Lutherans included the NC together with the Apostolic and the Athanasian Creed in their book of confessions. ${ }^{34}$ They did so to demonstrate their continuity to the apostolic and catholic tradition of the Ancient Church, but ironically, they adopted the NC in the Western, "filioquistic" form as well as the Athanasian Creed, despite its name, is a genuinely Western creed which has never been acknowledged by the Eastern churches. So there is a tension between the ecumenical intention due to which the Lutherans maintained the old Creeds, and the particularistic form of the Creeds they actually referred to.

The Calvinists did not give the ancient Creeds that prominent a place. ${ }^{35}$ And stronger than the Lutherans they insisted that the Creeds only are valid as far as they corresponded to the Holy Scripture. But although that led to quite different perceptions of the relevance of church traditions and Creeds to contemporary church doctrine and ecclesiastical life, it is, to my opinion, only a difference in emphasis. As to the hermeneutical principles, Lutherans and Calvinists agreed to a large extent: Both based the truth of theological claims only on their correspondence to the Scripture; and both stated any knowledge about God only to be unfolded out of the revelation of His grace. Melanchthon's famous mottos that the secrets of the Divinity be rather adored than investigated, ${ }^{36}$ and that knowing God means knowing his benefits (Hoc est Christum cognoscere beneficia eius cognoscere), ${ }^{37}$ are characteristic to the approach of all the reformers to the doctrine of the triune God. There is no doubt that this biblical, "economical" approach for the time being gave a strong support to the Filioque because it seemed evident that, if the Holy Spirit "economically" is being sent by the Son, the Spirit eternally must proceed from the Son, too. ${ }^{38}$ By that (to

33. Cf. Gunther Wenz, Theologie der Bekenntnisschriften der evangelisch-lutherischen Kirche. Eine historische und systematische Einführung in das Konkordienbuch, Vol. I, Berlin / New York 1996, esp. 143-166, 551561, 579-585. See also Jan Koopmans, Das altkirchliche Dogma in der Reformation, German translation by H. Quisdorp, München 1955 (Wageningen 1938).

34. Cf. Die Bekenntnisschriften der evangelisch-lutherischen Kirche [BSLK], Göttingen 91982, 19-30.

35. As a famous example, see Calvin's controversy with Petrus Caroli 1537. Cf. Koopmans, loc. cit., 45-48. See also my Filioque, 279.

36. "Mysteria divinitatis rectius adoraverimus quam vestigaverimus", Loci communes (1521), StA II/1, 6,16 sq.

37. CR 21, 85 (Loci, 2nd edition, 1535).

38. In the second half of the 16th century, this was one of the arguments Lutheran theologians from Tübingen used in their dialogue with Jeremias II, Patriarch of Constantinople. Cf. Dorothea Wendebourg, Reformation und Orthodoxie. Der ökumenische Briefwechsel zwischen der Leitung der Württembergischen Kirche und Patriarch Jeremias II. von Konstantinopel in den Jahren 1573-1581, Göttingen 1986. See also my Filioque, 282-295. 
quote John Polkinghorne) "bottom-up" approach the Reformers prefigurated the renaissance of trinitarian thinking in the 20th century.

The Filioque problem was not treated very intensively until, after the 1st Vatican Council, Roman Catholic Christians in Germany, Switzerland and the Netherlands left their church in protest against the dogma of papal infallibility and founded the Altkatholische (or in Switzerland: Christkatholische) Kirche. ${ }^{39}$ Because they felt a familiarity to the orthodox understanding of the church, they sought quite immediately to come into contact with orthodox theologians and clerics and started negotiations to overcome the impediments to full community of the churches. ${ }^{40}$ They could easily accept the orthodox complaint about the unauthorized changing of the Creed and returned soon to the original version of the NC. A long discussion followed on how to judge the Filioque as a theological doctrine, which was controversial but ended in 1970 with the official rejection of any doctrine entailing a causative participation of the Son in the procession of the Holy Spirit. ${ }^{41}$ In 1978, the Anglican Lambeth Conference also recommended its member churches to omit the Filioque in liturgy but emphasized the theological value of the Augustinian tradition. ${ }^{42}$ In 1995, a Vatican document ${ }^{43}$ quite surprisingly approved the Greek text of the NC to be the authoritative form of the Creed for the Roman catholic church and underlined the crucial meaning of the Father's mono-principality for the understanding of God's trinitarian being, but at the same time maintained the Latin NC as being not a translation of NC but rather a legitimate regional confession of faith with a long tradition of its own, and defended the Filioque as being an expression of the consubstantiality of Father and Son or Son and Spirit which would not contradict the Father's mono-principality. In the Protestant churches the discussion is still in a state of flux. While the Vereinigte Evangelisch-Lutherische Kirche in Deutschland 1997 strictly rejected any alteration of the Creed, ${ }^{44}$ scholars such as Jürgen Moltmann ${ }^{45}$ and Wolfhart Pannenberg ${ }^{46}$ argue in favour of a change, and ecumenical research groups reflect on the conditions on which such a change could be realized in a responsible way.

\section{The Dimensions of the Problem - Critique and Anti-Critique}

Why do Orthodox churches since Photios continuously regard the Filioque as being an impediment to the ecumenical unity of the church? I would like to focus the variety of objections on four arguments:

39. To the following, cf. my Filioque, 296-349.

40. Cf. Franz Heinrich Reusch (ed.), Bericht über die am 14., 15. und 16. September [1874] zu Bonn gehaltenen Unions-Conferenzen, Bonn 1874; idem (ed.), Bericht über die vom 10. bis 16. August $1875 \mathrm{zu}$ Bonn gehaltenen Unions-Conferenzen, Bonn 1875.

41. Cf. Erklärung der Internationalen Altkatholischen Bischofskonferenz zur Filioque-Frage" von 1970, in: IKZ 61 (1971), 69f.; Glaubensbrief der Internationalen Altkatholischen Bischofskonferenz, in: IKZ 61 (1971), 6568.

42. Cf. The Report of the Lambeth Conference 1978, London 1979, 51. Cf. my Filioque, 526-532.

43. Päpstlicher Rat zur Förderung der Einheit der Christen: Die griechische und die lateinische Überlieferung über den Ausgang des Heiligen Geistes, in: US 50 (1995), 316-324. Cf. my Filioque, 532-545.

44. Stellungnahme der Kirchenleitung der VELKD $\mathrm{zu}$ einigen Fragen des Wortlautes des NicaenoConstantinopolitanums, in: VELKD-Informationen Nr. 81 (Mai 1998), 17-21; also published in: ÖR 47 (1998), 265-268.

45. Cf. his: Trinitat und Reich Gottes, München 1980, also his contribution to the Klingenthal conferences (Vischer, loc. cit., 144-152). See also his: Der Geist des Lebens. Eine ganzheitliche Pneumatologie, München 1991, 320-324, displaying a stronger critique of the Western tradition.

46. See his Systematische Theologie, vol. I, Göttingen 1988, esp. 344-347. 
Firstly, changing the text of the NC is formally illegitimate. For the Council of Ephesus (431) explicitly prohibited any alteration of "the faith (or the Creed) of the Fathers assembled in Nicea" (DH 265). The Orthodoxy always understood that as a ban of any change within NC including even undoubtedly orthodox amendments.

Secondly, the addition of Filioque is also ecclesiologically illegitimate because it was carried out in a unilateral act of the Pope as the Patriarch of the West without seeking the ecumenical consensus in the community of the Patriarchs. Some orthodox theologians spoke of an act of lacking love and respect and even of a "moral fraticide" (Chomjakov).

Thirdly, the Filioque is theologically wrong because it destroys the trinitarian balance and order. By ascribing to the Son the capacity of being origin, it mixes the characteristics of the Father and the Son and thus qualifies the Father's mono-principality. It also subordinates the Spirit to the Son. But most importantly, as already mentioned, it contradicts the word of the Lord himself (John 15,26) that the Spirit "proceeds from the Father" although it is "sent" into the world by the Father and the Son.

Fourthly, the Filioque displays a wrong theological theory of knowledge because it is based on the assumption of a strict correspondence between the immanent and the economical order of the trinitarian relations. Yet, the distinction between eternal procession and temporary mission the Lord himself reveals (John 15,26) compels to contest such a strict correspondence. In the 14th century, Gregory Palamas even deepened the gap between eternal being and temporary acting by attributing the presence of God in the world to the eternal divine energies which are not only related to the trinitarian persons but to the transcendent divine essence. ${ }^{47}$ The doctrine of Palamas had an immense renaissance in the orthodox thinking of the 20th century but, in my view, the orthodox theologians now tried to link the divine energies stronger to the trinitarian persons. At least, that would be the only way the Palamite doctrine could reckon on any support in the West.

In the 19th and 20th century, Russian philosophers like Chomjakov and, inspired by them, neo-Palamite theologians integrated the Filioque critique into an extensive and radical criticism of the Western culture as a whole. The Filioque appeared to be the indicator if not root of any degeneration they diagnosed in the Western church and world. The subordination of the Spirit to the Logos-Son reflects (or has even inaugurated) the occidental rationalism in general and the disdain of the Spirit of the church in particular, and this disdain displays in protestant individualism as well as in Roman Catholic authoritarianism that locates the presence of the Spirit rather in the hierarchy of the clergy than (as it should be) in the totality (pleroma) of the church. Although not all orthodox theologians share this radical criticism, a nexus between the formal and the material aspect, that means, between the unilateral introduction of the Filioque into the common Creed and the alleged subordination of the Spirit to the Son is widely accepted.

Beginning about in the sixties of the 20th century, for several reasons this criticism has had increasing resonance within the Western churches:

Firstly, the renewal of trinitarian thinking in the 20th century did not imply a simple return to the dogmatic formulas of the past that had been rejected by modern age thinkers as being supranatural. Trinitarian theology rather had to be unfolded out of its biblical roots, and that compelled to intensive biblical studies on the one hand, and to review critically the dogmatic tradition including the Filioque on the other hand.

47. Cf. Dorothea Wendebourg, Geist oder Energie. Zur Frage der innergöttlichen Verankerung des christlichen Lebens in der byzantinischen Theologie, München 1980; Reinhard Flogaus, Theosis bei Palamas und Luther. Ein Beitrag zum ökumenischen Gespräch, Göttingen 1997. 
Secondly, within the ecumenical movement, the different churches saw themselves confronted with a broad range of other churches and traditions quite closer than before and had to examine their own traditions within the horizon of these different approaches to Christianity. There also arose the question of a commonly shared Creed, and thus the efforts to regain a joint text of the NC got a specific Sitz im Leben and a new urgency.

Thirdly, in the Western churches a feeling of spiritual impoverishment became widespread, and whereas the great liberal historians like Harnack had outlined a picture of the paralysed Orthodoxy that could not compete with the cultural power of the Western churches, there now emerged a new interest in orthodox spirituality and orthodox criticism of religious life in the West.

Fourthly, the culture of Western modernity lost its innocence and had to face the problems it had caused. Modernity had to reflect on itself. A fundamental criticism of modern rationalism, individualism etc. arose which overlapped with orthodox criticism making it attractive also to Western people.

Yet, this can hardly lead to a simple adoption of orthodox criticism and orthodox hermeneutics and conceptions. Why not?

Firstly, if there is an interaction between the Filioque and rationalism, logocentrism, individualism, authoritarianism etc., then why should there not also be a correlation between the rejection of the Filioque and, for example, the orthodox refusal of women being ordained or the nationalism that seems to be quite dominant in countries with strong orthodox influence? Despite similarities at the surface, there is a manifest difference between post-modernism and anti-modernism, and I would not take it for granted that the orthodox criticism of modernity fits in every respect with the motives and aims of domestic self-criticism in the West. We also have to ask ourselves if we are willing to live in a society where rationality is replaced by a so-called holistic approach and the freedom of individual choice is denounced in the name of a so-called spirit of community. If the Filioque were a symbol and even a source of rationality and freedom of the individual, and if the critique of the Filioque implied a holistic anti-rationalism and anti-individualism, I would not hesitate to deliberately defending it. But I doubt that such kind of strict correlation exists between the Filioque problem and cultural evolution. And so, at least, I would neither regard the orthodox criticism of Western culture as being a convincing argument against the Filioque nor the Western emphasis on rationality and freedom as being a sound argument in its favour.

Secondly, we have to keep in mind that the Orthodox hermeneutical approach to the doctrine of Trinity differs considerably from the Western approach. And if my argument is right that trinitarian thinking, due to the conditions of Western modernity, can only be based on a strict correspondence between the temporary ("economical") mutual relations of the trinitarian persons and their eternal ("immanent") relations, then the orthodox questioning of that correspondence has become even more problematic than it was in premodern times. My thesis is that a critique of the Filioque can only be justified if it shows that the Filioque is an insufficient expression of the complex relations between Christ and the Holy Spirit in the history of God's caring grace towards the world. Orthodox arguments can help to examine the Western tradition in this regard, and they can provide models that may (or may not!) be more appropriate to express the relations between the divine persons, than the Filioque is. But even if that turns out to be the case, these arguments have to be transferred into a "Western" framework of thinking.

If this is true, we also have to take the old and new Western anti-criticism into consideration that refers to all of the mentioned aspects of the problem: 
a) The formal aspect: Whether the canon of Ephesus (431) which prohibited any "alteration of the faith or Creed of Nicea" actually intended to protect the words of NC may be doubted, because the NC was not known as the Creed of 381 before Chalcedon (451), and in Chalcedon it was quoted beside the Nicean Creed and thus even then was obviously not the only Creed. In the West, the Ephesus canon used to be interpreted as banning any alteration of the sense of the Nicean faith that would allow amendments to the Creed clarifying its sense with regard to a specific polemical situation. And the West always claimed that the Filioque was such a clarifying amendment. Yet, on the other hand, the orthodox theologians rightly stated that after the Ephesinum there have always been confessions beside the NC and theological clarifications of the sense of $\mathrm{NC}$, but never amendments to $\mathrm{NC}$ - except the Filioque. Not even the Photian ek monou tou patros was added to the Creed itself.

b) The ecclesiological aspect: There is no simple and generally applicable answer to the question whether or on what conditions an ecclesiastical decision is legitimate or not. In the different denominations quite different ways of defending legitimacy have been established. So the question whether the Western church had the right to alter the NC is dependent on how the respective denomination today defines the structures and methods of achieving authentic decisions. And it also depends on the relevance and authority the respective denomination ascribes to the ancient Creeds. Why, for example, should a Roman Catholic challenge the legitimacy of the addition of the Filioque if the Roman Catholic ecclesiology gives the pope the right to decide on behalf of the universal church? And why should a Lutheran in principle contest the right of changing the Creed when the Lutheran ecclesiology qualifies the status of the Creeds with reference to the Holy Scripture? Thus, the orthodox argument is not necessarily a sufficient reason for other churches to return to the original version of the Creed. There must be other reasons to justify such a far-reaching decision.

c) \& d) The trinitarian and hermeneutical aspects: There are actually sound arguments supporting the Filioque. If the Holy Spirit is the "Spirit of Christ" and if Christ "sends" the Spirit who subsequently makes Christ present to the Christians, then it seems almost compulsory to assume that this relation is not accidental but rather proves to be the revelation of an eternal relation in God himself. Conversely, there are also profound arguments against the Greek ek monou tou patros. Would it not imply an even stronger subordination than the Filioque did, because it subordinates not only the Spirit but also the Son to the Father (the orthodox theologian John Meyendorff quite frankly spoke of a "legitimate subordination" - but legitimate on the basis of what legitimation?)? And would a disproportionate emphasis on God's transcendence (Father) not follow from that - casting a shadow upon God's self-revelation (Son and Spirit)? And does the Orthodoxy not neglect the task of describing the eternal relations between the Son and the Spirit? In my opinion, it is evident that it is not the Orthodox conception of the Trinity as such that supplies sufficient arguments against the Filioque and compels us to revise our trinitarian thinking. My thesis is rather that a thorough examination of the Western as well as the Eastern trinitarian tradition leads to aporetic results that give us the chance to start anew, not beyond the differences of denominational perspectives and cultural settings, but beyond the fixed stereotypes of a long history of controversial debates. 


\section{Aporetic aspects of the trinitarian traditions - a challenge to a new approach}

I stated that the renaissance of trinitarian thinking in the Western churches in the 20th century basically involved the conviction that all our knowledge of God's triune being derives from the canonical witnesses of God's acting towards and in the world. That and how God is triune is not primarily an information revealed, so-to-speak, by a voice from heaven but rather is being mirrored in the way the divine persons relate to each other in the history of salvation. Although that correspondence between the "economical" and the "immanent" trinity at first sight seems to require the Filioque due to the Pentecostal mission of the Spirit by the Father and the Son, at second sight things prove to be quite more complicated. I only name two crucial aspects.

Firstly, the range of mutual relations between the Son and the Spirit witnessed in the Scripture is much larger than what the term Filioque displays. The Spirit is not only sent by the Son, but also enables the incarnation of the Son and comes onto the Son after his baptism leading him and giving him force to fulfil his mission. The relations between the Son and the Spirit are not as one-sided as the Filioque suggests. If this is true, why should this mutuality not be an essential element of their eternal relationship? In the Western tradition, this was prevented by the doctrine that the trinitarian persons are only distinguished by relations of origination that cannot be mutual for logical reasons. But is this restriction to relations of origination still convincing? Of course, this question also refers to the Orthodox tradition that bases the personality of the Son and the Spirit on their respective origin from the Father. Yet, in addition to these basic relations, Orthodox theologians have started to formulate different kinds of relations between the Son and the Spirit that may be suitable to express their mutuality. But why should these relations not also be essential to their respective personality?

Secondly, the Western tradition since Augustine emphasized that the different divine actions towards and in the world cannot be attributed exclusively to single divine persons: opera trinitatis ad extra sunt indivisa. Neither is creation exclusively a work of the Father, nor incarnation exclusively a work of the Son, nor redemption exclusively a work of the Holy Spirit. Strictly taken, then, the history of salvation does not reveal the characteristics of the divine persons and their relations but only their undistinguishable community. If we nevertheless relate creation to the Father, incarnation to the Son and redemption to the Holy Spirit, this is only a matter of "appropriation", that means: we observe a specific similarity of creation to the eternal characteristics of the Father and so on, and, due to that similarity (in the case mentioned, that would e.g. be generativity), we appropriate a specific work to a specific person although it is actually not linked to this person in a stronger way than to the other two. In his ingenious treatise on the trinity, Karl Rahner showed that, according to this conception, in a very strict sense it is accidental which one of the divine persons has been incarnated. ${ }^{48}$ But if the history of salvation does not unveil the characteristics of the divine persons, then where do we know these characteristics from?! It turns out that it is a very selective choice of biblical testimonies by which the picture of the trinitarian persons is being formed. And far from being a "bottom-up" approach starting with the Heilsgeschichte, it rather comes close to the orthodox hermeneutical model that our knowledge of God's triune being derives from an inspired information revealing nothing but the names of the divine persons and their elementary relations of origin. If we really

48. Cf. Karl Rahner, Der dreifaltige Gott als transzendenter Urgrund der Heilsgeschichte, in: Johannes Feiner / Magnus Löhrer (eds.), Mysterium Salutis. Bd. II: Die Heilsgeschichte vor Christus, Einsiedeln / Zürich / Köln 1967, 317-401, esp. 320. 
want the knowledge of trinity to be rooted in the Heilsgeschichte, we will have to modify the axiom of the opera ad extra indivisa: Indeed, the trinitarian persons do all their work towards and in the world strictly in common; yet, they do it not indistinguishably, but rather in a concrete order of community which may differ with reference to the respective work. Creation, then, is a work of the trinity in a different order than incarnation is. And all of these orders supposedly have relevance to our understanding of God's eternal being.

In my opinion, this approach would not only reflect the broad range of biblical witnesses with respect to what they may contribute to our knowledge of the triune God. Conversely, it could also bring the doctrine of Trinity closer to the testimonies of God's creative, justifying and redeeming work in the world and thus closer to our experiences and our language of faith. Instead of being an anachronistic relict of an metaphysical era that no longer helps us to understand ourselves, our world and our final destination, the doctrine of God's triune being could help to express our different and complex experiences with reference to God's distinct and multiform presence in the world.

Unfortunately, this will not necessarily imply that the doctrine of the trinity will have a simpler shape. Quite contrarily, the complexity will increase. Since the persons are not any longer distinguished and characterized by only one type of relation, namely the relation of origin, a "more complex structure of relations" (Pannenberg) $)^{49}$ will have to be established where any relation has its own character. The relation of the Father to the Son is categorically different from his relation to the Spirit, and the same goes for the relations between the Son and the Spirit or between the Spirit and the Father and so on. One of the most difficult tasks will then be to maintain the unity of that complex and dynamic structure.

As to the Filioque problem, the Western churches will have to tackle its theological implications within the horizon of the outlined scenario. In my view, from a deliberately Western and modern perspective, the Filioque turned out to be not a wrong (nor even heretic!) but an insufficient and one-sided expression of the relations between the Son and the Spirit. It is nevertheless a reminder of the indispensable truth that the Holy Spirit is essentially the Spirit of Christ. It is therefore not a theological necessity for the Western churches to return to the original text of the NC. But they can approve that step if the Eastern churches clearly declare that the Filioque is not a heresy and that the Holy Spirit essentially is the Spirit of the Son. I would think that, for gaining a commonly shared Creed, this is worth trying.

49. “...reicher strukturierte(s) Beziehungsgeflecht”, Systematische Theologie I, loc. cit., 348. 